\title{
Prospects For The Application Of The Kpi System In Tourism During The Digitalization Process
}

\author{
${ }^{1}$ Farkhod Ozodovich Abdullaev, ${ }^{2}$ Nurulla Bakhromovich Fayzullaev \\ ${ }^{1}$ Director of the Urgench branch of the Academy of Public Administration under the President of the Republic of Uzbekistan. \\ ${ }^{2}$ Head of the Department of Accounting and Auditing, Faculty of Tourism and Economics, Uzbekistan.
}

\begin{abstract}
This article analyzes the increase in efficiency in the process of digitization of economic sectors. It also highlights the prospects for the next phase of the application of the KPI system in the tourism sector of the economy which is a global business, taking advantage of the opportunities of digitalization and innovation.
\end{abstract}

Keywords:

KPI, digitalization, management, tourism, market, system, IT, digital economy, tourism industry, GDP.

Article Received: 18 October 2020, Revised: 3 November 2020, Accepted: 24 December 2020

\section{Introduction}

In the context of globalization, external migration, international trade and capital movements, tourism, foreign investment, IT development affect the economic growth rates of countries. Nowadays, market institutions around the world are experiencing a digital transformation [1].

Blockchain technology, cryptocurrencies are also part of the digital economy. But the Digital Economy means the economy in which digital communications are carried out using IT. At the same time, it can also be seen as a means of eliminating the shadow economy. Because, firstly, all transactions are registered electronically, and secondly, they are transparent.In countries with developed digital economies, both the volume of GDP and the share of GDP per capita are high. In this regard, the great attention of the head of our state to this issue has one goal, which is, firstly, to improve the living standards of the population, and secondly, to increase the real income of the population and to please our people.

In many developed countries today, digital technologies serve the development of the economy and the well-being of the population. For example, the experience of countries such as the United States, the European Union, China, Korea, Japan and Russia in regulating the development of the digital economy by the state shows that there are two main approaches - market and administrative approaches.

In particular, the automation of management, the achievement of the digital transformation of the services market in turn is an effective way of development[2].

Employee assessment is a process of determining the performance of personnel in order to achieve the goals of the company according to established indicators, which allows you to obtain the necessary information for making further management decisions in the field of motivation. One of the most effective assessment methodsemployees is a method based on the application of KPI that is, key performance indicators that allow you to evaluate the effectivenessthe actions performed by the organization as a whole, by departments and by each specific employee [3].

\section{Materials and methods}

The use of KPIs is implemented both on the example of the entire organization and in terms of individual departments and employees. The system allows you to build a motivational and effective remuneration system at the enterprise through indicators. In this case, a prerequisite is that the indicators can be measured. There are two main 
categories of indicators - qualitative and quantitative. Quantitative - these are financial indicators that characterize the efficiency of work, including revenue, profit, accounts receivable. Qualitative, in turn, are non-commercial indicators - fulfillment of the client visit plan, timeliness of submission of reports, staff turnover, and so on. In order to use this system any field of real sector of economics it is neccecey to know from what to start to what to stop. The picture below which is grouped by authors shows general sytematic view of inatial standart forms of using KPI in the real sector of economy.

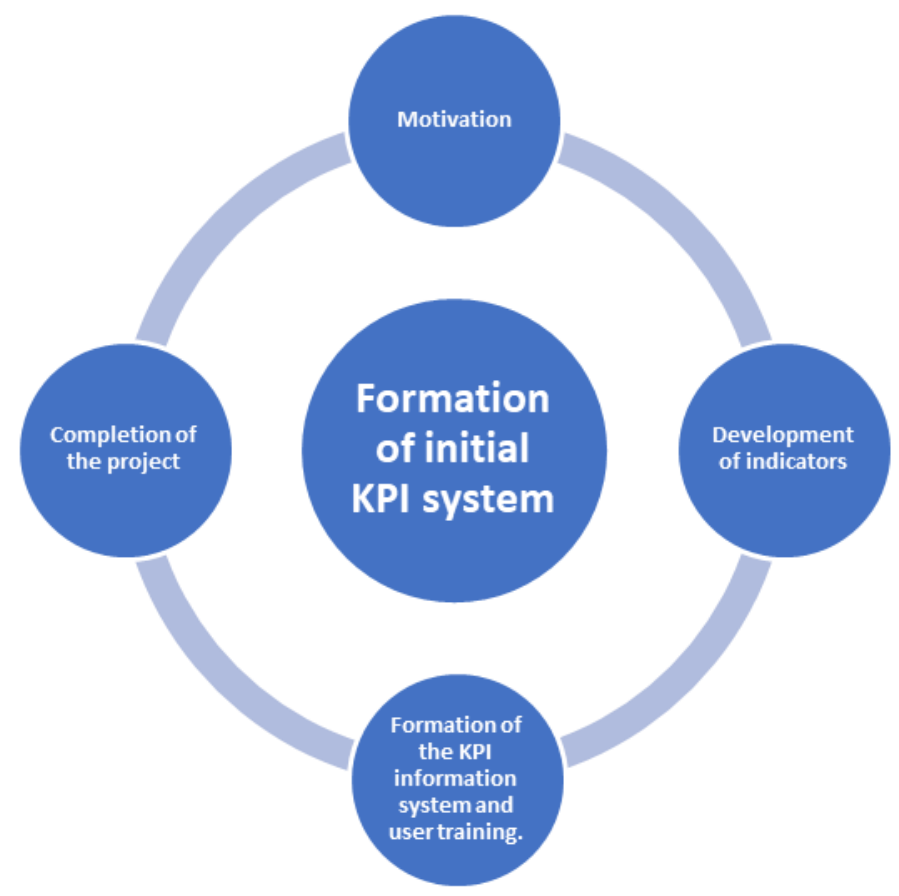

Pic.1 :Formation of initial KPI system for the real sector of economy.

\section{KPI system requirements:}

- indicators should be clearly defined;

- indicators and goals must be achievable;

- fluctuation in the indicator should depend on the person who is being evaluated;

- indicators should be directly related to the purpose of the organization.

\section{Motivation}

The system of formation of remuneration stimulates the employee to promote the growth of both his individual results and collective indicators and the achievement of strategic goals. The indicators in this case should be clear and understandable for the employee. The classic motivational formula is calculated as the sum of a fixed salary (salary) and a variable (variable) part. If the organization pays bonuses, then the size of the salary will be equal to the sum of its fixed and variable parts with bonus payments.

\section{Development of indicators}

The KPI development process must be carried out in several stages:

1. Pre-design work:

- approval and support from the top management of the organization;

- initiation and planning of a working project;

- formation of a working group;

- conducting pre-project methodological studies.

2. Methodological support of the KPI system:

- improvement of the existing organizational structure;

- modeling modern organizational processes through the introduction of performance indicators;

- development of organizational management processes based on KPI; 
- development of regulatory and methodological documentation.

3. Formation of the KPI information system and user training.

\section{Completion of the project.}

KPIs are metrics that measure the performance of each employee to achieve overall results. In other words, it is a "meter" of how productive travel agency employees are to achieve their desired goals.

A KPI-based incentive system is required for [4]:

- ensuring control over long-term and current performance indicatorsenterprises;

- assessing the personal effectiveness of a specific employee, department and organization inthe whole;

- orientation of employees to achieve the set results;

- managing the budget for the wages fund and reducing the time spent on

its calculation;

- ensuring collective and individual responsibility for the resultsactivities of the organization.

\section{In tourism industry.}

In the 21 st century, the activities of tourism enterprises are not complete without the use of information and digital technologies. In order to survive in the age of competition, it is necessary to introduce innovative technologies. In such cases, travel agents and tour operators of travel services must develop and apply new types of services that not only appeal to the tourist, but also be unique.

For this, it becomes necessary to form new consumer values:

- Comprehensive service by expanding the range of additional services;

- Improvement of the customer's postsale support;

- Introduction of international service standards.

Effective work of employees means getting a profit for the travel company. But what is meant by effective? The KPI system is designed to sort through the abstract concept of a "good employee" (Table 1) [5].

The main condition is that the indicators are individual. So, it makes absolutely no sense to compare the KPI of a manager who has been working in a travel agency for the third year fulltime, and an intern who had no previous experience in the tourism business.

The use of key performance indicators (KPIs) is becoming more common in business[6].

\begin{tabular}{|c|c|c|c|}
\hline Indicators & Calculation \% & Performance & Index coefficient \\
\hline $\begin{array}{llr}\text { Revenue from the } & \text { the } \\
\text { provision of tourism } \\
\text { services }\end{array}$ & $\begin{array}{l}\text { (Sales fact / Sales plan) } \\
100 \%\end{array}$ & $\begin{array}{l}<50 \% \\
51-69 \% \\
70-89 \% \\
90-100 \% \\
>100 \%\end{array}$ & $\begin{array}{l}0 \\
0,5 \\
0,8 \\
1 \\
1,5\end{array}$ \\
\hline $\begin{array}{l}\text { Number of sold tourist } \\
\text { vouchers }\end{array}$ & $\begin{array}{l}\text { (Sales fact / Sales plan) } * \\
100 \%\end{array}$ & $\begin{array}{l}<50 \% \\
51-69 \% \\
70-89 \% \\
90-100 \% \\
>100 \%\end{array}$ & $\begin{array}{l}0 \\
0,5 \\
0,8 \\
1 \\
1,5\end{array}$ \\
\hline $\begin{array}{l}\text { The number of tourists } \\
\text { served, the cost of one } \\
\text { person-tour, } \\
\text { implementation of a } \\
\text { plan }\end{array}$ & $\begin{array}{l}\text { Revenue for the period / } \\
\text { (number of tourists * } \\
\text { average } \\
\text { tour cost) } * 100 \%\end{array}$ & $\begin{array}{l}<60 \% \\
61-89 \% \\
90-100 \% \\
>100 \%\end{array}$ & $\begin{array}{l}0 \\
0,7 \\
1 \\
1,5\end{array}$ \\
\hline
\end{tabular}




\begin{tabular}{|l|l|l|l|}
\hline Complex tours & (Sales fact / Sales plan) $*$ & $<50 \%$ & 0 \\
$100 \%$ & $51-69 \%$ & 0,5 \\
$70-89 \%$ & 0,8 \\
$90-100 \%$ & 1 \\
\hline $\begin{array}{l}\text { Number of new } \\
\text { attracted clients }\end{array}$ & $\begin{array}{l}\text { (number of people in this } \\
\text { period / number of people } \\
\text { in the previous period) } * \\
100 \%\end{array}$ & 1,5 \\
\hline & $<100 \%$ & 1,5 \\
\hline
\end{tabular}

Table 1 - Values of the KPI coefficient in a tourism enterprise [5]

Another similar indicator is the introduction and free implementation of recommendations to optimize the organization's activities.

Accounting for such an indicator should motivate employees to optimize business processes in the organization.

\section{Indicator values can be:}

1 - no suggestions from the optimization employee were received;

1.05 - recommendations for optimization were received that would slightly increase performance, or enhance the convenience of data processing, but an opinion was received to refuse to implement these proposals;

1.1 - recommendations for optimization were received, the implementation of which slightly increased performance, or improved the convenience of data processing;

1.3 - suggestions from an optimization employee were received, the implementation of which significantly increased productivity.

The indicator "quality of work performed" is assessed based on the availability of information about absenteeism, disciplinary sanctions, delays, deviations from production technology [6].

Indicator values can be:

0.6 - insignificant violations of work discipline or deviations from the indicated requirements for the performance of work, which did not entail a decrease in the volume of production;

0.8 - big shortcomings in activity;

0 - there are violations of work discipline or requirements for completing tasks, which led to disruptions in the work of the department, a decrease in production;
Analyzing the situation in the company through KPI - management, it is possible to draw conclusions about whether the company has achieved its goals and objectives. In terms of specific numbers, it is easier to draw conclusions, quickly make changes, optimize the work process and costs. This is the first major benefit of KPIs.

\section{Digitalization and Tourism}

The creation of all conditions for attracting tourists to our country and the development of domestic tourism, the development of existing ones is considered one of the urgent tasks of today. Indeed, the focus on the development of this sector is an important source of the economy and plays a leading role in the formation of GDP, employment and welfare of the population. The work being done to support and encourage this sector is yielding positive results. That is, due to clearly targeted and systematic measures, the formation of advanced, modern aspects of tourism is being achieved.

Consistent development of the tourism industry in Uzbekistan has allowed Uzbekistan to be included in various international rankings with high performance in this area.In particular, in 2019, Uzbekistan was recognized as one of the most popular tourist destinations by about 10 leading publications (The New York Times, USA, The Guardian, UK), rating companies and portals (CrescentRating, Wegoplace).In early 2020, the UN World Tourism Organization recognized Uzbekistan as the fastest growing country in the field of tourism. In the ranking, it took the fourth place, leaving behind such countries as South Korea, Turkey, Azerbaijan and Kazakhstan. 
It should be noted that the improvement of industry statistics in 2018 allowed the Republic of Uzbekistan for the first time to enter the statistical collection "Compendium of Tourism Statistics 2013-2017" of the World Tourism Organization[7].

In this regard, great work is being done in our country on the development of modern information and communication technologies, the creation of an integrated system of e-government services, the introduction of new mechanisms of communication between government agencies and the population.

To achieve this goal, a document was adopted to ensure the implementation of the Decree of the President of 19 February 2018 "On measures to further improve the field of information technology and communications", as well as the development of digital economy, introduction of modern information technologies, information security [8].

In Uzbekistan most importantly, a step-bystep programmatic effort has been launched to accelerate the development of the industry. In particular, the legislative framework for reforming the tourism sector and regulating the tourism industry has been improved. In 2018-2019 alone, more than 20 regulatory documents were adopted to regulate the industry, and the number of tourism organizations increased by $75 \% .147$ events on access and development of domestic tourism were held.

Until 2025, the construction of hotels in Uzbekistan based on innovative technologies will be accelerated. In 2019, it was planned to build another 212 new hotels with a total number of rooms 4664. Modern hotels have been built in Tashkent (41), Samarkand (30) and Bukhara (29), which are in high demand and attract the most tourists. By 2021, their number will be gradually increased, and by this time a total of 1,508 new hotels with a total number of rooms of 30,212 will be built.

Nowadays, the attraction of various foreign investments is also an important factor in the success of major projects in the industry [9].
It should be noted that currently there is no common understanding among many authors on the development, formation and introduction of the digital economy (innovation) in the service sector (tourism) infrastructure. In our opinion, the scope of research that still needs to be conducted in this area is wide, and we must take into account the well-established international experience in ensuring the balanced development of industries.

The KPI system for a tourist enterprise should be created taking into account the specifics of its activities, important business processes, as well as other factors that significantly affect the performance of the company. The main task in the development and implementation of an incentive system using the KPI method is to correctly define and calculate indicators, make them understandable for staff and easy to evaluate. It is necessary to regularly monitor the effectiveness of the indicators used and their replacement or adjustment, if necessary.

\section{Conclusion}

In today's digital environment, in order to effectively use the KPI system in the tourism industry, we must first achieve the following results.

- it is necessary to create a single online data exchange system for existing tourism organizations. Through the system, it is possible to quickly exchange regulatory documents, reports, mutual information from all regions. This will allow all tourism organizations in the region to receive information at the same time;

- development of the concept of digitization of the market of tourism services in coordination with local governments

- development of indicators that allow to study the overall potential of the regions and conduct field surveys

- full digitization of all documentation related to personnel working in the field 
- formation of a system for publishing annual reports that transparently show the main indicators of each region in the field of tourism

\section{References}

[1] Abdullaev, F.O., Khamraev, K.I., Arzuova, S.A. and Abdukayumov, A.N., 2019. Digital Transformation of Market Institutions. Journal of Southwest Jiaotong University, 54(3).

[2] Abdullaev, F.O. and Ismailov, A.B., 2020. DIGITAL TRENDS IN THE SYSTEM OF STATE ADMINISTRATION AND PUBLIC SERVICES: EVIDENCE FROM UZBEKISTAN. Journal of Critical Reviews, 7(14), pp.289-291.

[3] Marr, B., 2012. Key Performance Indicators (KPI): The 75 measures every manager needs to know. Pearson UK.

[4] Kupriyanovsky, V., Konev, A., Sinyagov, S., Namiot, D., Kupriyanovsky, P. and Zamolodchikov, D., 2016. Optimizing the use of resources in the digital economy. International Journal of Open Information Technologies, 4(12), pp.86-96.Vancouver

[5] Zaitseva N.A.Use of key performance indicators (KPI) to assess the work with personnel at the enterprises of the tourism industry // Service in Russia and abroad. 2011. No. 2

[6] Bhatti, M.I., Awan, H.M. and Razaq, Z., 2014. The key performance indicators (KPIs) and their impact on overall organizational performance. Quality \& Quantity, 48(6), pp.3127-3143.

[7] World Tourism Organization., 2018. COMPENDIUM OF TOURISM STATISTICS 2018: Methodological Notes to the Tourism Statistics... Database 20122016. WORLD TOURISM ORG.

[8] Decree of the President of the Republic of Uzbekistan dated February 19, 2018 "On measures to further improve the field of information technology and communications." www.lex.uz
[9] Pan, W. and Wei, H., 2012, October. Research on key performance indicator (KPI) of business process. In 2012 Second International Conference on Business Computing and Global Informatization (pp. 151-154). IEEE. 